\title{
Semiquantitative analysis of genetically modified maize and soybean in food
}

\author{
María Laura Cazzola \\ Centro de Investigación y Desarrollo en Criotecnología de Alimentos \\ Facultad de Ciencias Exactas \\ Universidad Nacional de La Plata \\ Calle 47 y 116 (1900) La Plata, Argentina \\ Tel/Fax: 54221 4249287/4254853 \\ E-mail: lauracazzola@yahoo.com.ar \\ Silvana Petruccelli* \\ Centro de Investigación y Desarrollo en Criotecnología de Alimentos \\ Facultad de Ciencias Exactas \\ Universidad Nacional de La Plata \\ Calle 47 y 116 (1900) La Plata, Argentina \\ Tel/Fax: 54221 4249287/4254853 \\ E-mail: silvana@biol.unlp.edu.ar
}

Financial support: MTHA-UNLP (Maestría de Tecnología e Higiene de Alimentos de la Universidad Nacional de La Plata) and Federación BioquímicaPcia. Buenos Aires. SP is member of the research career of CONICET (Argentina).

Keywords: Bt maize, genetically modified organisms, semi-quantitative PCR, RR-soybean, transgenic food.

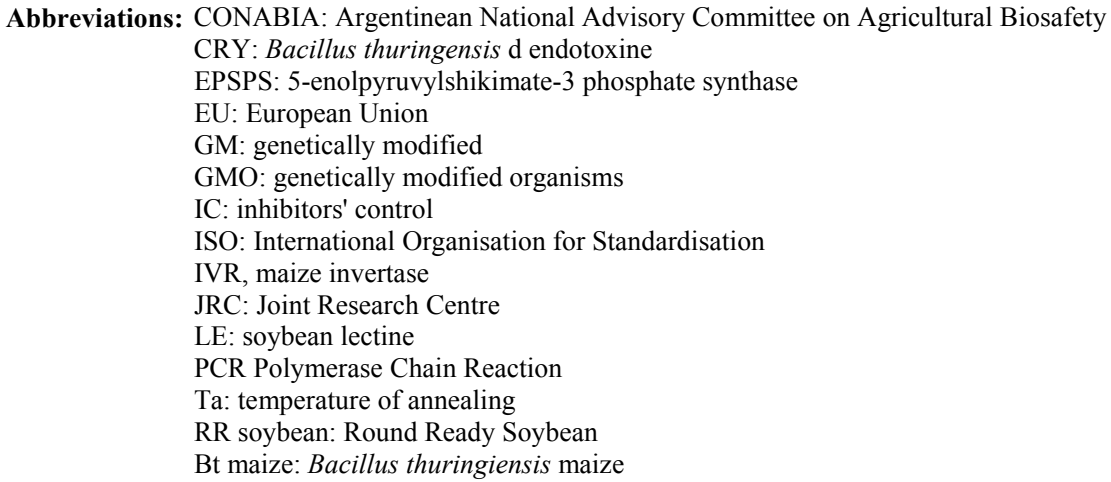

The aim of this study was to analyze quantitatively the presence of genetically modified organism in food with different composition and degree of processing. Total DNA was extracted by Dellaporta's method and GMO analysis was performed using two consecutives PCR reactions with specie specific primers (IVR and LE), screening primers (35S) and transgen specific primers (CRY and EPSPS). The quantification within the sensitivity establish by the EU was possible only in some foods (ice-cream, flours, soybean isolates and concentrates, starch). Samples with high lipid content or subjected to intense thermal treatments (such as some snacks, mayonnaise, creamy soup) could not be amplified mainly due to the presence of PCR inhibitors. Therefore the method was adequate for identification of food as GM, within the limits establish by $\mathrm{EU}$, only for some Argentine an commercial food products. These findings showed that the develop method was satisfactory only for simple food that were not subject to intense thermal treatments and that do not have high lipid content and that the main limitation of the method is DNA purity.

During the last nine years genetically modified plant's growing area has increased in an exponential way (James, 2004). In Argentina, only eight crops (one soybean, five maizes and two cottons) carrying genes that confer tolerance to glyphosate or amonniun glufosinate or resistance to lepidoptera have been approved for commercialization (CONABIA). Although in our country labeling of GM food is not required; several countries have established threshold levels for the unintentional mixing of GMOs with food products, therefore exported foods and ingredients should fulfill these regulations. In this regard,

*Corresponding author 
Table 1. Primers used in PCR.

\begin{tabular}{|c|c|c|c|c|c|}
\hline Primer & $5^{\prime}$ to $3^{\prime}$ Sequence & Target & $\mathrm{Ta}$ & Product & Method \\
\hline $\begin{array}{l}\text { IVR1 } \\
\text { IVR2 }\end{array}$ & $\begin{array}{l}\text { 5'-CCGCTGTATCACAAGGGCTGGTACC-3' } \\
\text { 5'-GGAGCCCGTGTAGAGCATGACGATC-3' }\end{array}$ & Maize Invertase & $68^{\circ} \mathrm{C}$ & $226 \mathrm{bp}$ & Specie specific \\
\hline $\begin{array}{l}\text { LE1 } \\
\text { LE2 }\end{array}$ & $\begin{array}{c}\text { 5'-AAGCAACCAAACATGATCCTC-3' } \\
\text { 5'-ATGGATCTGATAGAATTGACGTTA-3' }\end{array}$ & Soy lectin & $44^{\circ} \mathrm{C}$ & $407 \mathrm{bp}$ & Specie specific \\
\hline $\begin{array}{l}35 S-1 \\
35 S-2\end{array}$ & $\begin{array}{l}\text { 5'-GCTCCTACAAATGCCATCA-3' } \\
\text { 5'-GATAGTGGGATTGTGCGTCA-3' }\end{array}$ & CaMV 35S & $55^{\circ} \mathrm{C}$ & 195 bp & Screening \\
\hline $\begin{array}{l}\text { GM07 } \\
\text { GM08 }\end{array}$ & $\begin{array}{l}\text { 5'-ATCCCACTATCCTTCGCAAGA-3' } \\
\text { 5'-TGGGGTTTATGGAAATTGGAA-3' }\end{array}$ & EPSPS & $57^{\circ} \mathrm{C}$ & $169 \mathrm{bp}$ & Transgene specific \\
\hline $\begin{array}{l}\text { CRY1 } \\
\text { CRY2 }\end{array}$ & $\begin{array}{l}\text { 5'-ACCATCAACAGCCGCTACAACGACC-3' } \\
\text { 5'-TGGGGAACAGGCTCACGATGTCCAG-3' }\end{array}$ & CrylA(b) & $71^{\circ} \mathrm{C}$ & $184 \mathrm{bp}$ & Transgene specific \\
\hline
\end{tabular}

the EU has very restrictive requirements; the Regulation (EC) No. 1830/2003 concerning to the traceability and labeling of GMO in food and feed products is in force (European Council, 2003) and establish the mandatory labeling of food and feed derived of GMO independent of the detection of DNA or protein and only allows an intentional contamination up to $0.9 \%$ for GMO approved or $0,5 \%$ for events not approved but with positive biosafety decision (Miraglia et al. 2004). In addition, since January 2005 the Regulation 178/2002 (European Commission, 2002), is in vigour and impose the traceability of each component or product along the complete food chain. To be able to fulfill these exigencies, methods to identify and quantify GMO in crude material, ingredients and end products are required. PCR is the most widely used technique to confirm the presence of GMOs because its sensitivity and specificity.

Nevertheless the detection of GMO in foods is very difficult because the matrixes are complex what do not allow an efficient DNA extraction, several PCR inhibitors are present, and in addition DNA suffers alteration during the food processing. The quantitative analysis of GMO in food and ingredients are still more complex, because among its component there are DNAs from different sources and the amount of DNA present in each ingredient will depend on its refinement degree. These facts have opened an intense debate about how the results must be expressed and if it is possible quantify with the limits required. There are also some discussions about the interpretation of the different regulations.
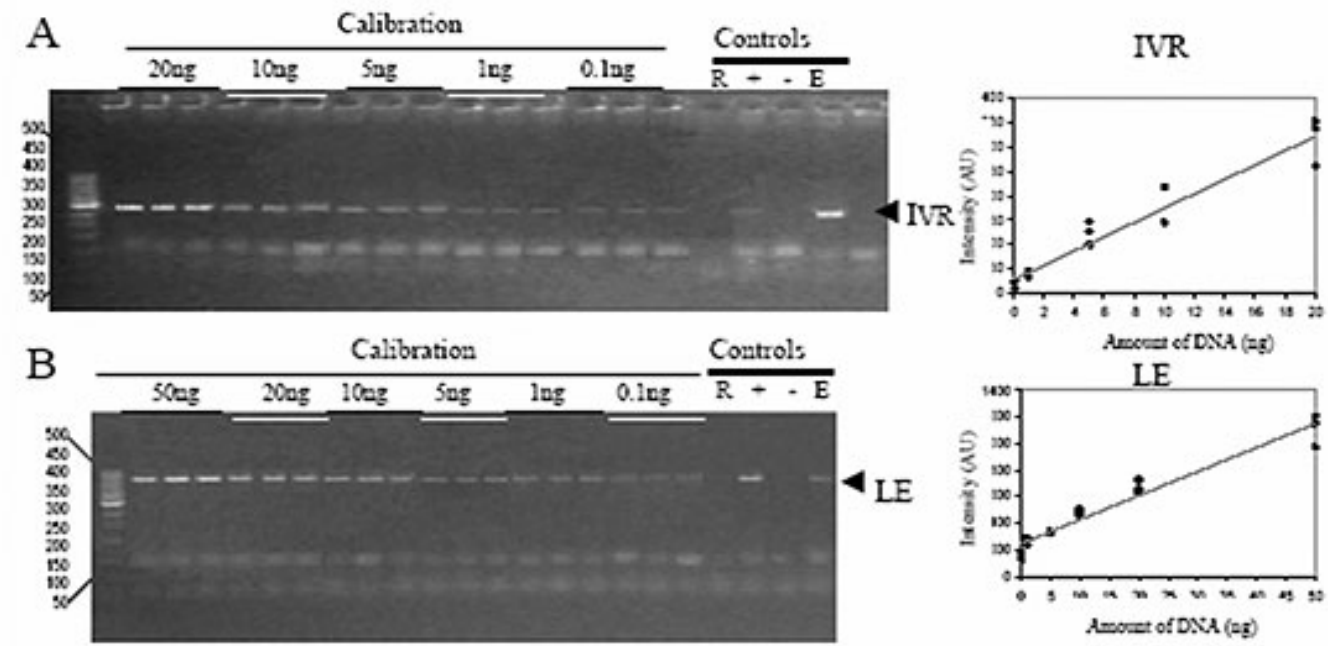

Figure 1. Analysis of the amount of maize (A) or soybean (B) DNA in the different food samples. Calibration curves were performed with different amounts of Bt 176 maize or RR soybean DNA with the primers IVR and LE, respectively. The used controls were: reactives (R); positives Bt 176 or RR soy DNA (+); negative no GMO DNA (-); DNA extraction (E). 


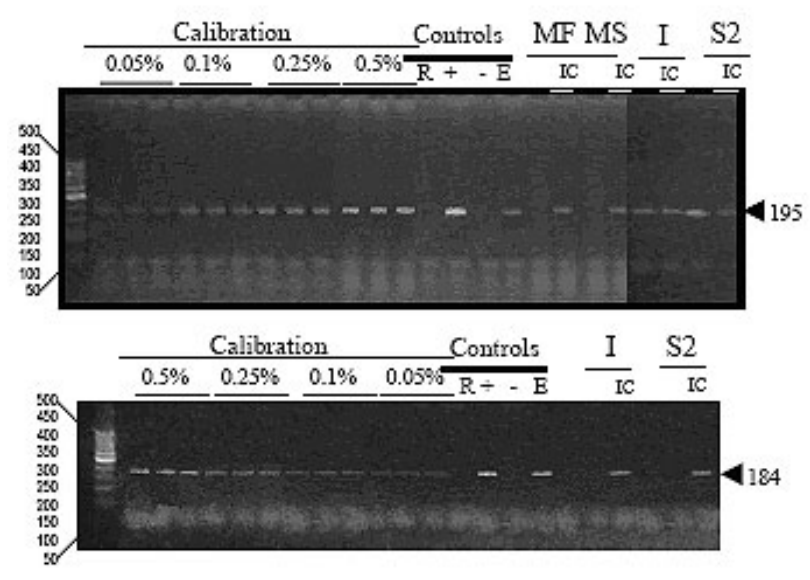

Figure 2. Analysis of $35 \mathrm{~S}$ promoter and CRY genes in food samples. The calibration curve was made with mixed flours containing diferent amounts of Bt176 maize. Four controls were performed: reactives (R); Bt 176 DNA (+); DNA no GMO (-); extraction (E). Samples: MF: maize flour; S2: maize starch 2; $\mathrm{SN}$ : maize snack; I: ice-cream; IC: inhibitor control.

At present, quantitative detection in food has been performed only in some model systems (Yoshimura et al. 2005a; Yoshimura et al. 2005b). The aim of this work was to set up a protocol to semi quantify GMO in foods with different composition and processing degree.

\section{MATERIALS AND METHODS}

\section{Samples}

Commercial food samples whose label state the presence of soybean or maize were used. In addition soybean isolates and concentrates were prepared in the laboratory.

\section{DNA extraction}

Genomic DNA was extracted according to Dellaporta et al. (1983).

\section{PCR}

Reaction conditions were adjusted to quantify with a threshold level of $0.05 \%$. To this end, different amounts of template and $\mathrm{MgCl}_{2}$, were assayed, and were finally set in $200 \mathrm{ng}$ template DNA and $4 \mathrm{mM} \mathrm{MgCl}_{2}, 0.2 \mu \mathrm{M}$ dNTPs, $0.2 \mu \mathrm{M}$ each primer and 5\% dimethyl sulfoxide. Two final point consecutive reactions of 35 cycles were performed.

For the calibration, DNA was extracted from flours prepared mixing different proportions GM/noGM grains (courtesy of GMO Food Analysis Service of INTA, Castelar, Argentina). The lineal range obtained was 0.05 to $0.5-1 \%$ GMO for the different sets of primers, that were taken from different published works (Meyer and Jaccaud, 1997; Pietsch et al. 1997; Gachet et al. 1999; Meyer, 1999), (Table 1). These primers are adequate for RR-soybean and the five maize approved for commercialization in Argentina and they have also been recommended by different organizations and/or regulations; e.g. primers 35S1/35S2 are suggested by Alimentarium Codex Commission and ISO; primers IVR1/IVR2 by ISO, primers GM07/GM08 by Join Research Center (JRC). Annealing temperatures were adjusted to obtain the maximum amount of PCR products with a minimal amount of primer dimers (Table 1). The amount of maize's or soybean's DNAs in the different

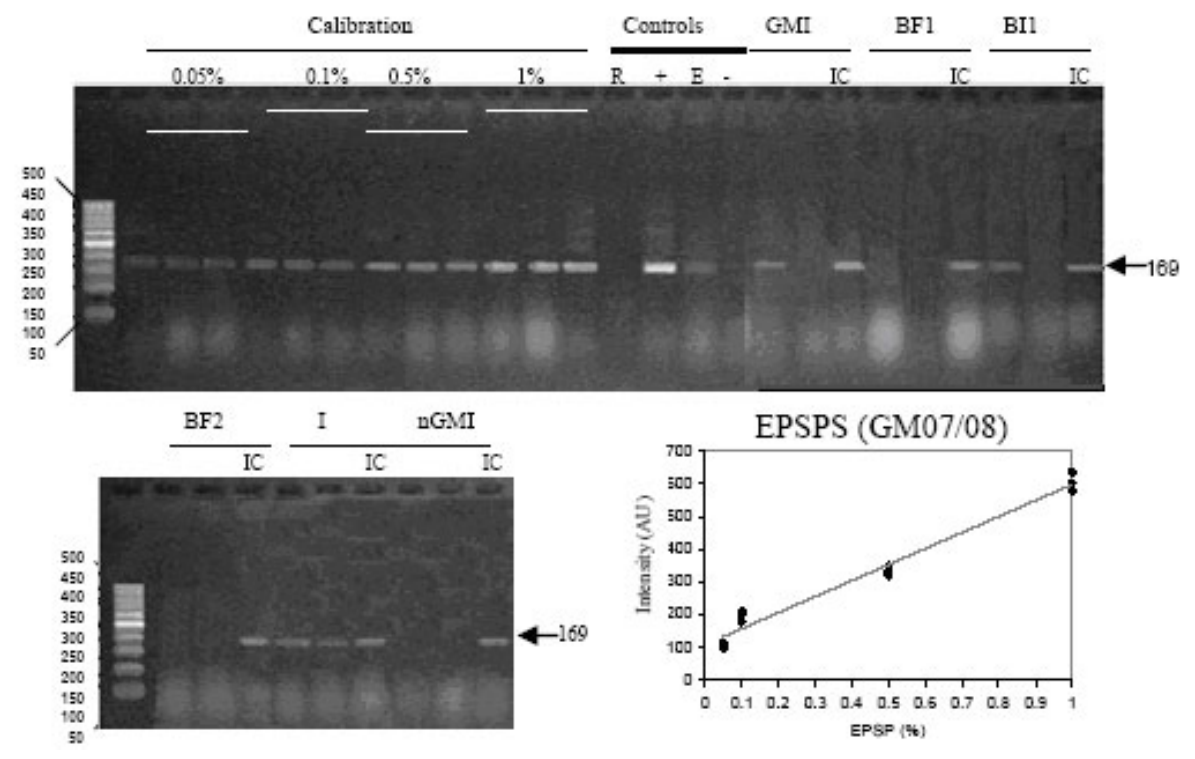

Figure 3. Analysis of EPSPS in DNA extracted from food samples. Calibration was performed with flour containing different amounts of RR soybean, GMI: RR soybean isolate; BF1: Brazil soy flour 1; BI1: Commercial Brazilian Isolate 1; BF2: Brazil soy flour 2; I: ice-cream; nGMI: no GM laboratory isolate. 
Table 2. Results of GMO analysis in foods.

\begin{tabular}{|c|c|c|c|}
\hline \multirow{2}{*}{ Foods } & \multicolumn{3}{|c|}{ Amplification } \\
\hline & IVR & $35 S$ & Cry \\
\hline Creamy Soup & - & ND & ND \\
\hline Maize Flour & + & $-(<0.05 \%)$ & ND \\
\hline Maiz Starch 1 & + & $-(<0.3 \%)^{\#}$ & ND \\
\hline Honey & + & $-(<2,10 \%)^{\#}$ & ND \\
\hline Ice-cream & + & $4,86 \pm 0,25^{*}$ & $-(<0.05 \%)$ \\
\hline Pre-cooked Maiz Flour & $+(1 / 5)$ & $-(<0.05 \%)$ & ND \\
\hline Maize Starch 2 & + & $1,03 \pm 0,25^{*}$ & $-(<0.05 \%)$ \\
\hline Fried Potatoes & $+(1 / 10)$ & $-(<0.05 \%)$ & ND \\
\hline Maize Snack 1 & - & ND & ND \\
\hline Maize Snack 2 & - & ND & ND \\
\hline Maize Snack 3 & $+(1 / 10)$ & $-(<0.05 \%)$ & ND \\
\hline Popcorn & - & ND & ND \\
\hline \multirow[t]{2}{*}{ Maize-Oil } & - & ND & ND \\
\hline & Le & $35 S$ & EPSPS \\
\hline Lab GM Concentrate. & + & $>1$ & $>1$ \\
\hline Lab GM Isolate & + & $>1 \bullet$ & $>1 \bullet$ \\
\hline Argentinean Soy Flour & + & $3,32 \pm 0,03^{*}$ & $2,29 \pm 0,11^{*}$ \\
\hline Brazilian Soy Isolate 1 & + & $0,13 \pm 0,05$ & $0,10 \pm 0,11$ \\
\hline Brazilian Soy Isolate 2 & + & $\mathbf{0 , 5 0} \pm 0,04$ & $0,47 \pm 0,12$ \\
\hline Soy Juice & $-/ I C(-)$ & ND & ND \\
\hline Ice-cream & + & $4,79 \pm 0,05^{*}$ & $4,03 \pm 0,11^{*}$ \\
\hline Mayonnaise & $-/ I C(-)$ & ND & ND \\
\hline Brazilian Meal & + & $0,90 \pm 0,05$ & $<0,05$ \\
\hline Soy-Oil & $-/ I C(+)$ & ND & ND \\
\hline
\end{tabular}

-The different amounts of DNA used were over the calibration curve limits.

*Values were obtained by interpolation, but less of $200 \mathrm{ng}$ of genomic maize or soy DNA was used to be within the curve limits. \#The amount of maize or soybean DNA obtained after the food sample extraction was lower than $200 \mathrm{ng}$ therefore $0.05 \%$ sensitivity was not reached. preparations from food samples was quantified using the specie specific: IVR and LE primers, respectively. PCR products were separated in $2.5 \%$ agarose gels, observed with transilluminator UV $(\lambda 300 \mathrm{~nm})$ and photographed with a CCD camera. Images were analyzed with Kodak 1D Image software.

Following ISO 21570 recommendations (ISO, 2002), triplicates were carried out for each curve point. In addition four PCR controls were performed: I- reactives (R): no template, II-positive(+): addition of Bt 176 or RRDNA; III-negative(-): addition of DNA extracted from non transgenic maize or soybean, IV-extraction (E): addition of the minimal amount of transgenic DNA detectable by the method. At least duplicate PCR of each DNA extracted from food samples were carried out and the presence of PCR's inhibitors (IC) in these preparations was evaluated by addition of $20 \mathrm{ng}$ of transgenic DNA.

\section{RESULTS AND DISCUSSION}

The calibration curves obtained using different amounts of DNA from Bt 176 maize or RR soybean, have a lineal range among 0.1 to $20 \mathrm{ng}$ for reactions performed with the primers IVR and 0.1 to $50 \mathrm{ng}$ with the primers LE (Figure 1). Extracted DNA from foods that state in its label maize, such as creamy soup, maize flour, starch, ice-cream, fried potatoes and some snacks are amplified with the primers IVR (Figure 1 and Table 2). In contrast, DNA from other snacks, maize oil or popcorn can not be amplified (Figure 1 and Table 2). In the last group of samples, the control for PCR inhibitors was also negative therefore the purity of DNA was not sufficient. In the case of DNA prepared from food products containing soybean such as isolates, concentrates, flours and ice-cream purity was enough to obtain amplification products with the primers LE (Figure 1 and Table 2). However no amplification was observed for DNA purified from soybean juice, mayonnaise and soy oil. In the case of soybean juice and mayonnaise the lack of amplification was due to the presence of PCR's inhibitors in the DNA preparation (not amplification is observed in the IC reactions) and in the case of oil, whose content of DNA is very low, the extraction yield was not sufficient (in this samples IC was positive).

These results suggest that the DNA extraction method is adequate only for food products with low lipid content and that have not received intense thermal treatments such as flours, isolates, concentrates and ice-cream. Troubles in amplifying complex food samples even using more rigorous DNA extraction methods for example commercial kits has been reported by Peano et al. (2004) and the standardization of extraction methods to obtain pure enough DNA is one of the main challenges to fulfill regulation requirements.

Once the amount of maize or soybean DNA present in the different preparations from food samples was established, in the subsequent PCR, DNA was adjusted to $200 \mathrm{ng}$, 
because this amount is necessary to obtain $0.05 \%$ sensitivity with the semiquantitative PCR method adjusted in this work. Only positive samples for PCR with the primers IVR and LE were subsequently analyzed by PCR with screening (35S) and identification (CRY and GM07/08) primers. The results obtained for some maize samples are presented in Figure 2. Maize flours and snack sample 3 did not amplify with the primers $35 \mathrm{~S}$ therefore can be classified as no GM with the threshold level established by the EU (European Council, 2003); in contrast ice-cream and maize starch 2 are positives with the primers $35 \mathrm{~S}$ therefore should be labeled as GM.

However, these two samples were negative for transgenspecific reactions with the primers CRY, therefore the source of the transgene might not be any of the transgenic maize approved for commercialization in Argentina. Icecream sample was positive with primers GMO therefore contains soybean GM (Figure 3). Amplification with the primers 35S and GMO was also observed for laboratory prepared GM concentrates and isolates, Argentinean soy flour, commercial soybean isolates and Brazilian soy meal (Figure 3 and Table 2). The origin of the last two samples is Brazil, country that not allows RR soybean. The amount of $35 \mathrm{~S}$ and GMO were similar in all the samples in which quantification of GM soy was achievable (Table 2).

The results obtained for the different maize and soybean contained samples are summarized in Table 2 . Quantification with the threshold level fixed by EU was possible only in few samples that are commercialized in Argentina such as ice-cream, soybean flours and isolates, maize starch, Brazilian soybean flours and isolates. The last results are in concordance to a recent report that informed $50 \%$ of illegal cultivated RR soybean (Greiner et al. 2005). Nevertheless the detected GM in these Brazilian samples were very low therefore could be the result of an intentional contamination.

In conclusion, GMO quantification, in the conditions assayed in this work, was only possible for very simple food products that are not subjected to intense thermal treatment and their lipid content is low. The main limitation for the quantitative analysis of food samples was the quality of DNA obtained.

\section{REFERENCES}

DELLAPORTA, S.; WOOD, J. and HICKS, J. A plant DNA mini-preparation: version III. Plant Molecular Biology Reporter, 1983, vol. 41, no. 4, p. 19-21.

EUROPEAN COMMISSION. Regulation (EC) No 178/2002. Official Journal of the European Communities, 28 January 2002, L31, p. 1-24.

EUROPEAN COUNCIL. Regulation (EC) No. 1830/2003., of the European Parliament and of the Council, concerning the Traceability and Labelling of Genetically Modified
Organisms and the Traceability of Food and Feed Products Produced from Genetically Modified Organisms and Amending Directive 2001/18/EC. 15798/1/ 02 REV1. European Council, Brussels. In force 18 April 2004, 2003.

GACHET, E.; MARTIN, G.; VIGNEAU, F. and MEYER, G. Detection of genetically modified organisms (GMOs) by PCR: a brief review of methodologies available. Trends in Food Science and Technology, 1999, vol. 9, no. 11-12, p. 380-388.

GREINER, R.; KONIETZNY, U. and VILLAVICENCIO, A.L.C.H. Qualitative and quantitative detection of genetically modified maize and soy in processed foods sold commercially in Brazil by PCR-based methods. Food Control, 2005, vol. 16, no. 8, p. 753-759.

ISO 21570. Foodstuffs- Methods of analysis for the detection of genetically modified organisms and derived products- Quantitative nucleic acid based methods. International Organisation for Standardisation, Geneva. 2002.

JAMES, C. Preview: Global Status of Commercialized Biotech/GM Crops: 2004. International Service for the Acquisition of Agri-biotech Applications (ISAAA) Briefs, 2004, no. 32. ISBN 1-892456-36-2.

MEYER, R. Development and application of DNA analytical methods for the detection of GMOs in food. Food Control, 1999, vol. 10, no. 6, p. 391-399.

MEYER, R. and JACCAUD, E. Detection of genetically modified soya in processed food products: development and validation of a PCR assay for the specific detection of Glyphosate-Tolerant Soybeans. In: Proceedings of the EURO FOOD CHEM. (IX, $8^{\text {th }}-10^{\text {th }}$ September, 1997, Interlaken, Switzerland). Conference, 1997, p. 1, 23-28.

MIRAGLIA, M.; BERDAL, K.; BRERA, C.; CORBISIER, P.; HOLST-JENSEN, A.; KOK, E.; MARVIN, H.; SCHIMMEL, H.; RENTSCH, J.; VAN RIE, J. and ZAGON, J. Detection and traceability of genetically modified organisms in the food production chain. Food and Chemical Toxicology, 2004, vol. 42, no. 7, p. 1157-1180.

PEANO, C.; SAMSON, M.C.; PALMIERI, L. and GULLI, $M$. Qualitative and quantitative evaluation of the genomic DNA extracted from GMO and non-GMO foodstuffs with four different extraction methods. Journal of Agricultural and Food Chemistry, 2004, vol. 52, no. 23, p. 6962-6968.

PIETSCH, K.; WAIBLINGER, H.; BRODMANN, P. and WURZ, A. Screeningverfahren zur Identifizierung "gentechnisch veränderter" pflanzlicher. Lebensmittel. Deutsche Lebensmittel-Rundschau, 1997, vol. 93, no. 2, p. 35-38.

YOSHIMURA, T.; KURIBARA, H.; MATSUOKA, T.; KODAMA, T.; IIDA, M.; WATANABE, T.; AKIYAMA, 
Cazzola, M. L. and Petruccelli, S.

H.; MAITANI, T.; FURUI, S. and HINO, A. Applicability of the quantification of genetically modified organisms to foods processed from maize and soy. Journal of Agricultural and Food Chemistry, 2005a, vol. 53, no. 6, p. 2052-2059.

YOSHIMURA, T.; KURIBARA, H.; KODAMA, T.; YAMATA, S.; FUTO, S.; WATANABE, S.; AOKI, N.; IIZUKA, T.; AKIYAMA, H.; MAITANI, T.; NAITO, S. and HINO, A. Comparative studies of the quantification of genetically modified organisms in foods processed from maize and soy using trial producing. Journal of Agricultural and Food Chemistry, 2005b, vol. 53, no. 6, p. 2060-2069. 